\title{
Sarcoma of the Orbit Clinical TNM Finding v7
}

National Cancer Institute

\section{Source}

National Cancer Institute. Sarcoma of the Orbit Clinical TNM Finding v7. NCI Thesaurus. Code C88823.

A clinical finding about one or more characteristics of sarcoma of the orbit, following the rules of the TNM AJCC V7 classification system. Clinical classification should be based on the symptoms and signs related to loss of vision and visual field, degree of global displacement and loss of extraocular motility, and degree of compressive optic neuropathy. Diagnostic tests should include perimetry, ultrasonog raphy, computed tomography, magnetic resonance imaging, and other imaging procedures when indicated. (from AJCC 7th Ed.) 